\title{
SISTEM INFORMASI PENDAFTARAN DNA SEXING REPORT AWAN BIRD BERBASIS JAVA
}

\author{
Arif Setiawan', Yuni Wibawanti², Aulia Ar Rahman Awaludin ${ }^{3}$ \\ Program Studi Informatika, Universitas Indraprasta PGRI \\ arifsetiawan9217@gmail.com,yuniwib206@yahoo.com, aulia_awaludin@yahoo.co.id
}

Submitted October 8, 2019; Revised June 27, 2020; Accepted July 2, 2020

\begin{abstract}
Abstrak
Teknologi informasi yang bergerak dalam bidang usaha tes DNA Sexing Report atau pendaftaran DNA Sexing Report merupakam merupakan sistem yang masih jarang digunakan oleh usaha yang bergerak dalam bidang DNA sexing. Usaha Awan Bird merupakan usaha yang sistem pendaftarannya dan perhitungan masih terbilang masih manual dimana sistem tersebut belum terkomputerisasi. Tujuan penelitian ini untuk membuat sebuah perancangan suatu aplikasi Sistem Informasi Pendaftaran DNA Sexing Report yang dapat melakukan aktifitas sistem pendaftran dan pembayaran tes DNA serta pembuatan laporan yang lebih efisien. Metode yang penulis gunakan untuk membuat sistem informasi pendaftaran $D N A$ Sexing Report dengan mengunakan bahasa pemograman Java Netbeans dan MySQL. Penulis menggunakan Java Netbeans IDE 8.0.2 untuk pembuatan program dan MySQL sebagai sarana penyimpanan database. Hasil sistem yang dibangun dapat mempermudah admin dalam proses pendaftaran DNA Sexing Report dan pembayaran DNA Sexing Report sehingga leih mudah dalam pencarian data.
\end{abstract}

Kata Kunci : Sistem Informasi DNA, Sexing Report Awan Bird, DNA Sexing Report Mengunakan Java dan Database MySQL

\begin{abstract}
Information technology that is engaged in the DNA Sexing Report test business or registration of the DNA Sexing Report is a system that is still rarely used by businesses engaged in the field of DNA sexing. Awan Bird Business is a business with a registration system and the calculation is still fairly manual where the system has not been computerized. The purpose of this study is to make a design of an application for the DNA Sexing Report Registration Information System that can carry out the registration system activities and DNA test payments and report making more efficiently. The method the author uses to create a DNA Sexing Report registration information system using the programming language Java Netbeans and MySQL. The author uses Java Netbeans IDE 8.0.2 for making programs and MySQL as a database storage facility. The results of the system that was built can facilitate the admin in the process of registering DNA Sexing Report and payment of DNA Sexing Report so that it is easier to find data.
\end{abstract}

Key words: DNA Information System, Bird Birding Sex Report, DNA Sexing Report Using Java and MySQL Database

\section{PENDAHULUAN}

\section{Latar Belakang}

Berkembangnya ilmu pengetahuan dan teknologi, serta perkembangan teknologi informasi, maka komputer layak disebut sebagai alat bantu dalam perkembangan teknologi informasi, karena informasi sangat penting untuk mendukung kelangsungan perkembangan, sehingga terdapat alasan informasi sangat 
dibutuhkan bagi perusahaan terutama perusahan yang baru berkembang.

Sistem adalah suatu jaringan kerja dari prosedur-prosedur yang saling berhubungan, berkumpul bersama-sama untuk melakukan suatu kegiatan atau untuk menyelesaikan suatu sasaran yang tertentu serta data yang diolah menjadi bentuk yang lebih berguna dan lebih berarti bagi penerimanya[1][2].

Sistem informasi adalah suatu alat untuk menyajikan informasi sedemikian rupa sehingga bermanfaat bagi penerimanya. Tujuannya adalah untuk menyajikan informasi guna pengambilan keputusan pada perencanaan, pemrakarsaan, pengorganisasian, pengendalian kegiatan[3].

Sistem informasi pendaftaran DNA Sexing Report Awan Bird yang masih manual berbanding terbalik dengan perkembangan teknologi yang pesat. Dalam hal ini sistem informasi status pendaftaran DNA Sexing Report Awan Bird masih mengalami permasalahan yaitu proses pengolahan data dari devisi satu ke devisi lainnya masih dilakukan secara manual berupa pencatatan dan pengolahan data mengunakan buku besar, sehingga kurang baik dalam penyimpanan data dimana data tersebut rentan hilang dan dalam pencarian data tersebut memakan banyak waktu.

DNA Sexing Report merupakan pengembangan ilmu pengetahuan untuk mempermudah menditeksi keragaman ginetik suatu induvidu berbasis molekuler mengunakan metode Polymerase Chain Reaction (PCR).

DNA Sexing Report (Polymerase Chain Reaction, PCR) adalah suatu metode enzimatis untuk amplifikasi DNA dengan cara in vitro[4].

Tujuan dari penelitian ini adalah dapat membangun sistem informasi pendaftaran DNA Sexing Report yang dapat diaplikasikan oleh usaha Awan Bird dalam rangka meningkatkan kinerja, efisiensi, dan efektifitas informasi dalam hal sistem pendaftaran DNA Sexing Report.

Aplikasi ini dapat membantu usaha Awan Bird yang berkaitan dalam menangani permasalahan pengolahan sistem DNA Sexing Report untuk memenuhi kebutuhan pendataan dan perhitungan. Selain itu pihak pengelola DNA Sexing Report tidak lagi memerlukan waktu lama untuk menginput semua data pelanggan dan data pembayaran, sehingga dapat mengefisiensi waktu.

Dari hasil penelitian yang penulis lakukan, maka dapat diambil beberapa masalah yang dapat diuraikan sebagai berikut:

1. Belum adanya rancangan sistem pendaftaran yang dapat mengatasi permasalahan yang ada di usaha Awan Bird.

2. Perhitungan transaksi pembayaran masih dilakukan secara manual.

3. Dalam pencatatan dan penyimpanan data sering terjadi kesalahan dalam hal penulisan dan memungkinkan terjadinya kerusakan atau data hilang, dan tertukar serta sulit dalam mencari data karena semua proses masih manual.

4. Dalam pencarian laporan kurang cepat dan akurat.

Untuk menyelesaikan beberapa permasalahan diatas, maka diusulkanlah beberapa alternatif untuk menyelesaikan masalah tersebut diantaranya :

1. Sistem yang akan di buat pada DNA Sexing Report Awan Bird meliputi data pelanggan, data admin, data sempel, data pengiriman, data LAB dan pembuatan laporan.

2. Aplikasi berbasis desktop dengan mengunakan NetBeans IDE 8.0.2 dengan bahasa pemograman Java.

3. Perhitungan total pembayaran berdasarkan jenis burung yang dilakukan tes DNA dan berapa banyak jumlah sampel tes $D N A$. 
4. Laporan yang dibuat dalam data dan pemasukan selama satu bulan.

Sistem informasi pendaftaran DNA Sexing Report dibangun dengan bahasa pemrograman Java Netbeans. NetBeans adalah Integrated Development Environment (IDE) berbasis Java dari Sun Microsystems yang berjalan di atas Swing. Swing merupakan sebuah teknologi Java[5] untuk pengembangan aplikasi destop yang dapat berjalan diberbagai macam platfrom seperti, Windows, Linux, Mac Os X, and Solaris[2].

Netbeans merupakan salah satu IDE yang dikembangan dengan bahasa java Netbeans mempunyai lingkup pemograman yang terintegrasi dan satu perangkat lunak yang didalamnya menyediakan pengembangan pemograman GUI, text editor, compiler dan interpreter[6].

Dalam penelitian yang penulis buat megunakan $M y S Q L$ sebagai penyimpanan data, MySQL merupakan turunan suatu konsep utama dalam database sejak lama, yaitu SQL (Stuctured Query Language) sebuah pengoperasian database terutama untuk pemilihan dan seleksi dan pemasukan data, yang memungkinkan pengoprasian data dikerjakan dengan mudah secara otomatis[7].

\section{METODE PENELITIAN}

Pada penelitian ini, dalam membuat sistem informasi pendaftaran DNA sexing report menggunakan bahasa pemograman Java Netbeans dan MySQL.

Beberapa tahapan penelitian yang dilakukan sebagai berikut :

a) Pengamatan (Observasi) ini dilakukan untuk mempelajari perilaku manusia, proses kerja, dan gejala-gejala yang terjadi pada lokasi penelitian yang sedang berjalan saat ini.

b) Wawancara tahap ini dilakukan tatap muka dan tanya jawab langsung antara peneliti dan narasumber dengan harapan informasi yang diperoleh akurat.

c) Analisa dan perancangan terhadap sistem yang akan dibangun, seperti desain sistem, aturan sistem, pengolahan data dan laporan.

d) Pembuatan aplikasi dilakukan lalu diimplementasikan sehingga menjadi sebuah sistem dengan dasar bantuan literatur yang sudah dikumpulkan sebelumnya.

e) Uji coba merupakan suatu yang penting karena pada tahapan ini dapat dilihat kesalahan ataupun kekurangan dan ketidaksesuaian konsep yang dibuat.

\section{HASIL DAN PEMBAHASAN}

Untuk mempermudah penelitian ini maka dibuat model data yang paling fleksibel untuk membuat rancangan sistem yang akan dibuat.

ERD merupakan peralatan pembuatan model data yang paling fleksibel, dapat diadaptasi untuk berbagai pendekatan yang mungkin di ikuti perusahaan dalam pengembangan sistem[8].

Sebuah Entity Relationship Diagram (ERD) tersusun atas tiga kompenen yaitu entitas menunjukan objek-objek dasar yang terkait di dalam sistem, atribut merupakan keterangan-keterangan yang terkait pada sebuah entitas yang disimpan dalam basis data dan kerelasian antar entitas mendefinisikan hubungan antara dua buah entitas[9].

Jika dituangkan ke dalam Entity Relationship Diagram atau ERD, maka desain awal dari sistem ini adalah seperti gambar berikut: 


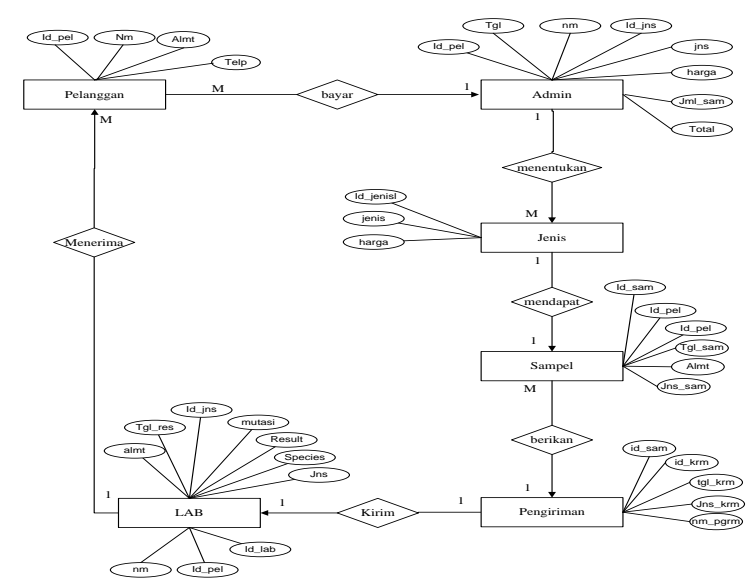

Gambar 1. Entity Relationship Diagram

Dimana Entity Relationship Diagram etitas pelangggan melakukan proses pembayaran kepada admin, dilanjutkan kedalam etitas jenis dimana dilakukan pemberian sampel jenis oleh bagian etitas jenis, selajutnya pemberian sampel yang dilakukan untuk pemberian sampel untuk sempel yang akan di kirim LAB, dan etitas pengiriman melakukan proses data pengiriman oleh sales untuk sampel yang dikirimkan keLAB, dan di tahap LAB memberikan data-data hasil LAB yang dikirim kepada pelanggan yang melakukan pelanggan.

Untuk mempermudah dalam membantu penelitian penulis maka penulis mengunakan Data Flow Diagram (DAD) sebagai respresentasi grafik yang menggambarkan aliran informasi dan transformasi grafik yang menggambarkan aliran informasi dan transformasi yang diaplikasikan sebagai data yang mengatur data masukan (Input) dan keluaran (Output)[10].

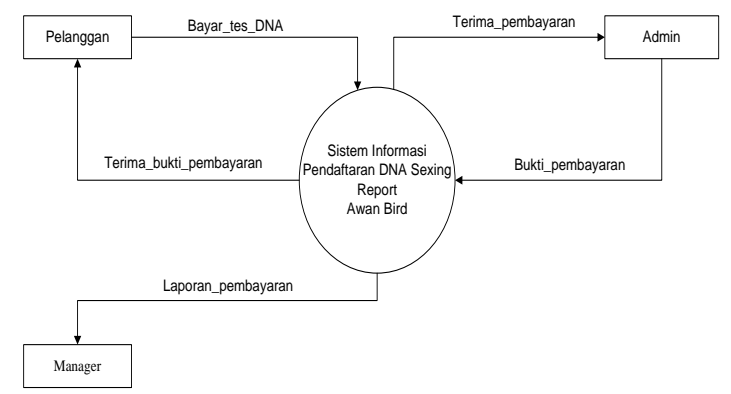

Gambar 2. Diagram Konteks Sistem Berjalan
Diagram alir data sistem informasi pendaftaran DNA Sexing Report Awan Bird yang berjalan menjelaskan dimana sistem tersebut masih mengunakan sistem yang manual dimana etitas pelanggan, etitas admin dan etitas manager mempunyai arus data bayar tes dna, terima pembayaran dimana arus data berhubungan langsung kedalam proses pendaftaran DNA Sexing Report yang berupa data pembayaran, data bukti pembayaran, menerima hasil dalam bentuk laporan pembayaran. Serta belum adanya proses pendaftaran dalam proses yang berjalan tersebut.

\section{Diagram Alir Data (DAD) Sistem yang Diusulkan}

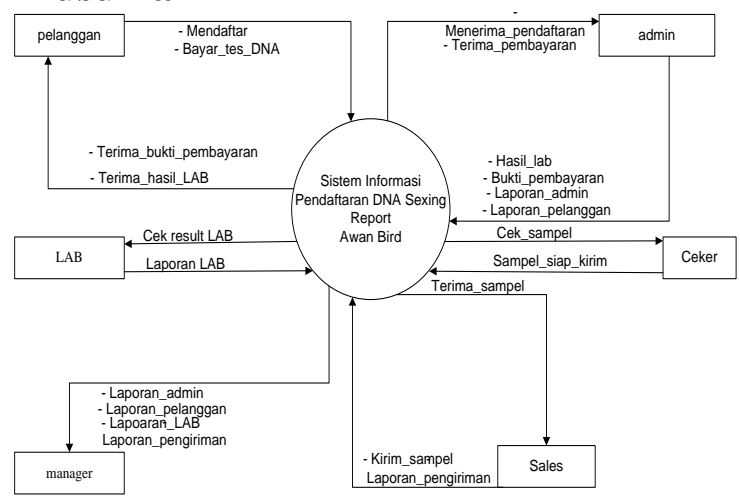

\section{Gambar 3. Diagram Konteks Sistem Diusulkan}

Diagram alir data sistem informasi pendaftaran DNA Sexing Report Awan Bird yang diusulkan menjelaskan dimana sistem tersebut mengunakan sistem yang terkomputerisasi dimana etitas pelanggan, etitas admin,etitas Admin, etititas ceker, etitas seles dan etitas manager mempunyai data pendaftaran, data bukti pembayaran, data result lab, data sampel, data pengiriman sampel, dan laporan yang berhubungan langsung kedalam proses pendaftaran DNA Sexing Report yang dimana data data tersebut di simpan kedalam data base dan semua sistem yang berjalan dilakukan secara terkomputerisasi yang hasil dari data tersebut dibuat sebagai 
laporan-laporan yang di serahkan kepada manager.

\section{Tampilan Login}

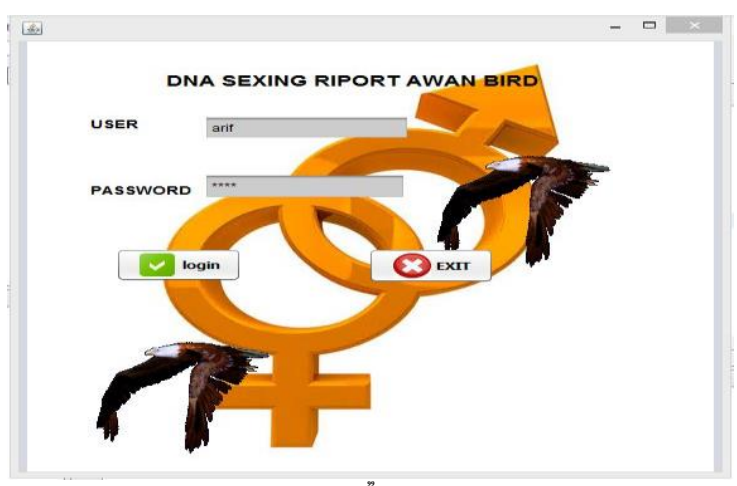

Gambar 4. Tampilan Form Login

Tampilan login adalah tampilan dimana admin harus masuk kemenu utama dengan terlebih dahulu memasukan data user dan password yang sesuai barulah admin bisa login kedalam menu utama sistem DNA Sexing Report.

\section{Tampilan Layar Menu Utama}

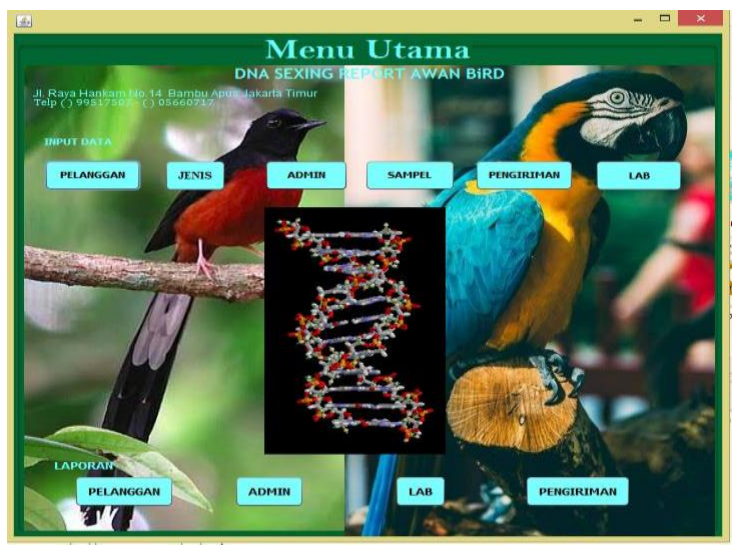

Sumber : Penulis, 2019

\section{Gambar 5. Tampilan Form Menu Utama}

Tampilan menu utama adalah tampilan dimana pertama kali user membuka aplikasi. Pada tampilan menu utama terdapat botton input data yang didalamnya terdapat menu data pelanggan, data jenis , data admin data sampel, data pengiriman, data LAB serta utama terdapat botton outputt yang didalamnya terdapat laporan data pelanggan, laporan data admin, laporan data LAB, dan laporan data pengiriman.

\section{Tampilan Layar Form Pelanggan}

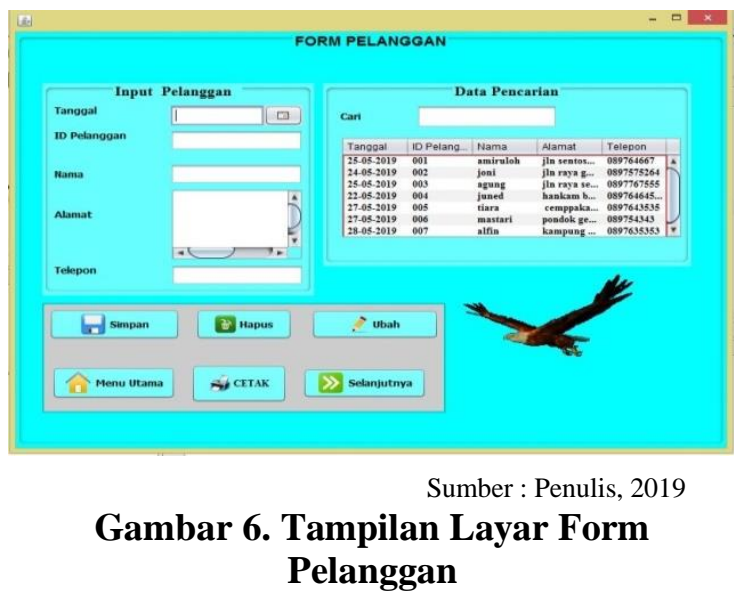

Form data pelanggan digunakan oleh user untuk meng-input, meng-edit, dan menghapus informasi data pelanggan yang mendaftar DNA Sexinng Report Awan bird serta memudahkan admin dalam pencarian data pelangan di dalam data pencarian. Terdapat button menu utama dimana akan kembali ke dalam menu utam yang dapat mempermudah user dalam masuk kembali kemenu utama. Dan terdapat button selanjutnya dimana memudahkan user untuk melanjutkan input data kedalam form lain. . Serta terdapat button cetak dimana berfungsi untuk mencetak data pelanggan sebagai laporan pendaftran data pelanggan.

\section{Tampilan Layar Form Admin}

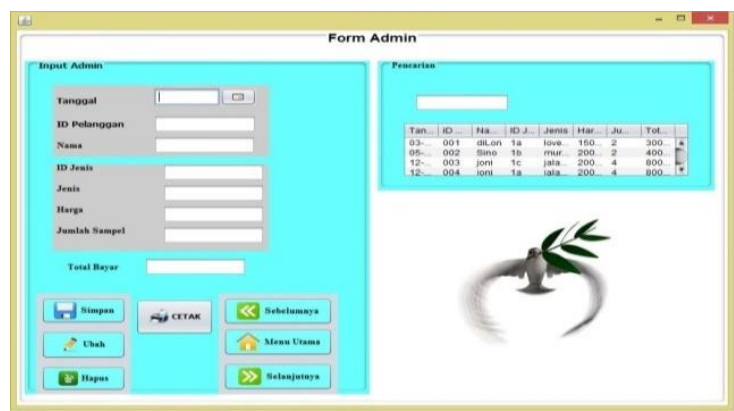

Sumber : Penulis, 2019

Gambar 7. Tampilan Layar Form Admin

Form data admin digunakan oleh user untuk meng-input, meng-edit, dan menghapus informasi data pembayaran 
DNA Sexing Report Awan bird serta memudahkan user dalam pencarian data pelangan di dalam data pencarian. Terdapat button menu utama dimana akan kembali ke dalam menu utam yang dapat mempermudah user dalam masuk kembali kemenu utama. Dan terdapat button selanjutnya dimana memudahkan user untuk melanjutkan input data kedalam form lain, button sebelumnya untuk kembali ke dalam form sebelumnya. Serta terdapat button cetak dimana berfungsi untuk mencetak data pembayaran sebagai laporan admin.

\section{Tampilan Layar Form Jenis}

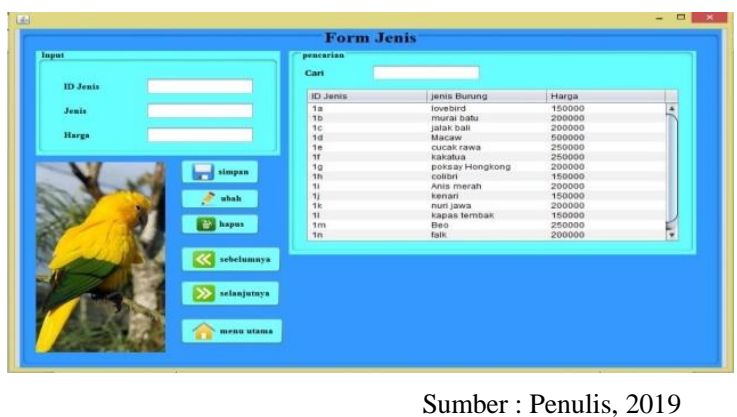

Gambar 8. Tampilan Layar Form Jenis

Form data jenis digunakan oleh user untuk meng-input, meng-edit, dan menghapus informasi data jenis yang berfungsi sebagai master data harga tetap tes DNA Sexinng Report Awan bird berdasarkan jenis dan harga tes dna. Serta memudahkan user dalam pencarian data jenis di dalam data pencarian. Terdapat button menu utama dimana akan kembali ke dalam menu utam yang dapat mempermudah user dalam masuk kembali kemenu utama. Dan terdapat button selanjutnya dimana memudahkan user untuk melanjutkan input data kedalam form lain, button sebelumnya untuk kembali ke dalam form sebelumnya.

\section{Tampilan Layar Form Sampel}

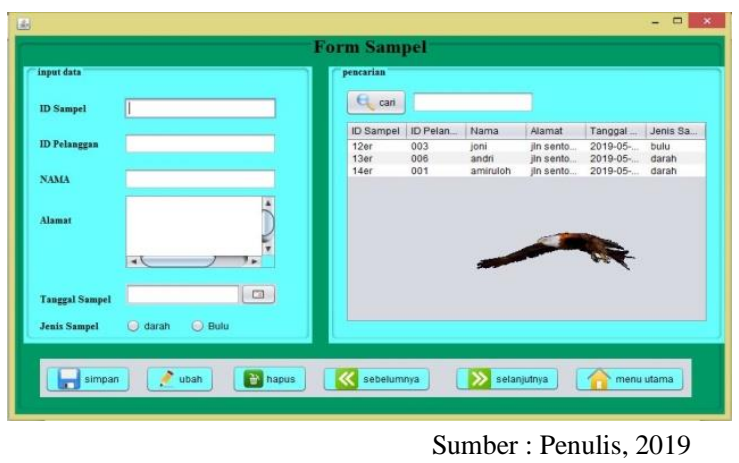

Gambar 9. Tampilan Layar Form Sampel

Form data sampel digunakan oleh user untuk meng-input, meng-edit, dan menghapus informasi data sampel yang berfungsi sebagai informasi data sampel DNA Sexing Report Awan Bird. Serta memudahkan user dalam pencarian data jenis di dalam data pencarian. Terdapat button menu utama dimana akan kembali ke dalam menu utama yang dapat mempermudah user dalam masuk kembali kemenu utama. Dan terdapat button selanjutnya dimana memudahkan user untuk melanjutkan input data kedalam form lain, button sebelumnya untuk kembali ke dalam form sebelumnya.

\section{Tampilan Layar Pengiriman}

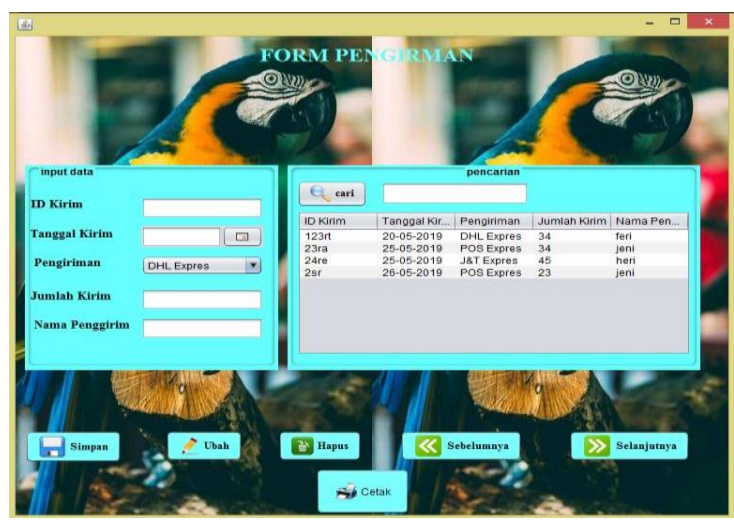

Sumber : Penulis, 2019

Gambar 10. Tampilan Layar Hasil Kalkulasi

Form data pengiriman digunakan oleh user untuk meng-input, meng-edit, dan menghapus informasi data sampel yang berfungsi sebagai informasi data pengiriman yang di kirim oleh kurir Awan 
Bird. Serta memudahkan user dalam pencarian data jenis di dalam data pencarian. Terdapat button menu utama dimana akan kembali ke dalam menu utama yang dapat mempermudah user dalam masuk kembali kemenu utama. Dan terdapat button selanjutnya dimana memudahkan user untuk melanjutkan input data kedalam form lain, button sebelumnya untuk kembali ke dalam form sebelumnya. Serta terdapat button cetak dimana berfungsi untuk mencetak data pengiriman sebagai laporan pengiriman.

\section{Tampilan Layar Form LAB}

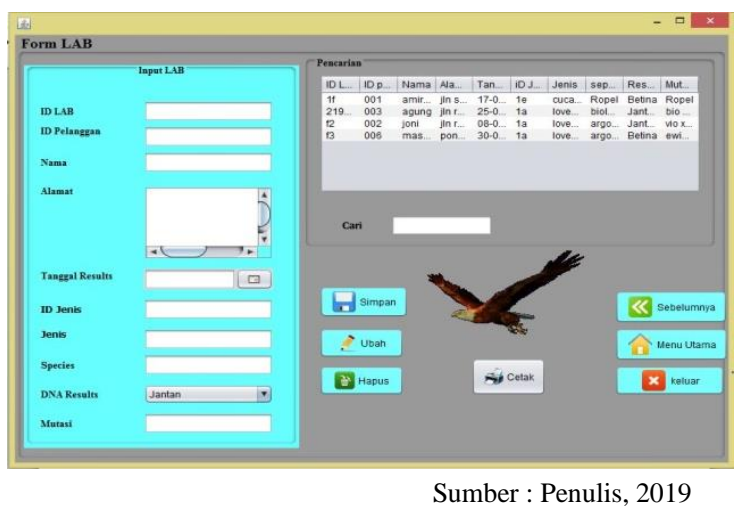

Gambar 11. Tampilan Layar Form LAB

Form data LAB digunakan oleh user untuk meng-input, meng-edit, dan menghapus informasi data sampel yang berfungsi sebagai informasi data lab. Serta memudahkan user dalam pencarian data jenis di dalam data pencarian. Terdapat button menu utama dimana akan kembali ke dalam menu utam yang dapat mempermudah user dalam masuk kembali kemenu utama. Dan terdapat button selanjutnya dimana memudahkan user untuk melanjutkan input data kedalam form lain, button sebelumnya untuk kembali ke dalam form sebelumnya. Serta terdapat button cetak dimana berfungsi untuk mencetak data lab sebagai laporan lab.

\section{Tampilan Layar Laporan Data Pelanggan}

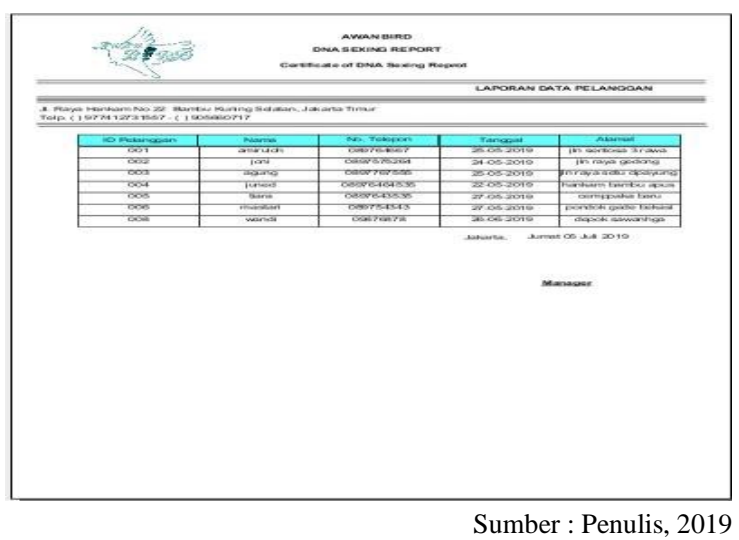

\section{Gambar 12. Tampilan Layar Laporan Data Pelanggan}

Lapoaran pelanggan dicetak sebagai laporan real untuk data pelanggan yang melakukan pendaftran tes dna sexing report sesuai dengan periode pendaftaran pelanggan yang sudah terdaftar.

\section{Tampilan Layar Laporan Data Admin}

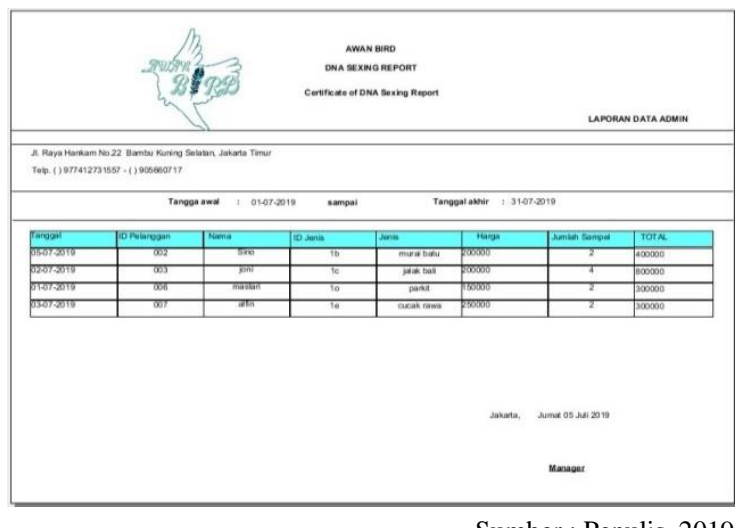

Gambar 13. Tampilan Layar Laporan Data Admin

Lapoaran admin dicetak sebagai laporan real untuk data pembayaran yang melakukan pendaftran tes dna sexing report sesuai dengan periode waktu yang sudah ditentukan apakah pembayaran sesuai dengaan pendaftran yang terdaftar di dalam data pelanggan yang melakukan tes DNA Sexing Report. 


\section{Tampilan Layar Laporan Data Pengiriman}

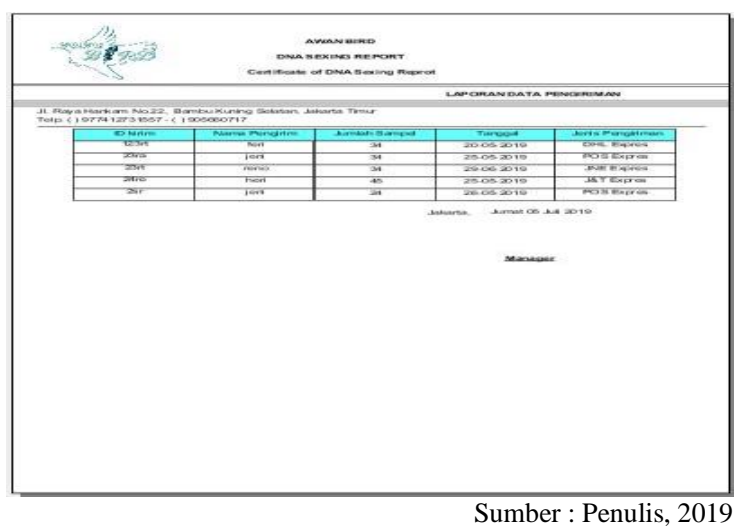

Gambar 14. Tampilan Layar Laporan Data Pengiriman

Laporan pengiriman dicetak sebagai laporan real untuk data pengiriman sampel oleh kurir sesuai dengan periode waktu yang sudah ditentukan apakah pengiriman sesuai dengaan waktu yang ditentukan sebagai informasi laporan pengiriman sesuai dengan periode yang ditentukan oleh admin.

\section{Tampilan Layar Laporan Data LAB}

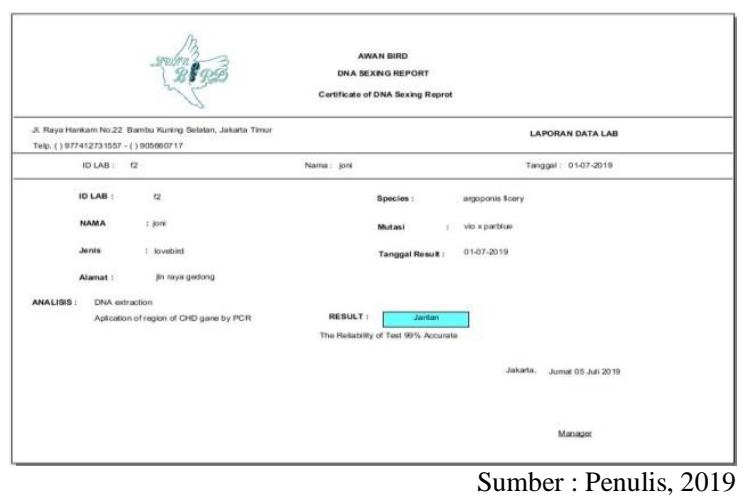

Gambar 15. Tampilan Layar Laporan Data Pengiriman

Laporan LAB dicetak sebagai laporan real untuk data result tes DNA Sexing Report Awan Bird sesuai dengan periode waktu yang sudah ditentukan. Dimana hasil laporan sebagai informasi admin apakah data pengiriman sampel sesuai dengan hasil lab yang keluar. Serta sebagai hasil laporan yang dibutuhkan untuk pelanggan sebagai hasil LAB dari tes DNA Sexing Report Awan Bird.

\section{SIMPULAN}

Berdasarkan hasil penelitian yang telah dilakukan penulis, maka dapat diambil simpulan bahwa sistem yang dihasilkan meningkatkan kinerja, efisiensi, dan efektifitas informasi dalam hal sistem pendaftaran DNA Sexing Report. Dengan dibuatnya Sistem informasi pendaftaran DNA Sexing Report memudahkan dalam proses pengolahan sistem DNA Sexing Report untuk memenuhi kebutuhan pendataan dan perhitungan transaksi pembayaran pada Awan Bird.

\section{DAFTAR PUSTAKA}

[1] M. K. Ruhul Amin, "Siswa Baru Pada Smk Budhi Warman 1 Jakarta,"ilmu pengetahuan dan teknologi komputer., vol. 2, no. 2, pp. 113-121, 2017.

[2] J. W. Crampton, "Mappings," Wiley-Blackwell Companion to Cult. Geogr., vol. 08, no. 50, pp. 423436, 2013.

[3] A. Rahmawati, R. Kridalukmana, and I. P. Windasari, "Pembuatan Sistem Informasi Rental Mobil dengan Menggunakan Java dan Mysql," J. Teknol. dan Sist. Komput., 2015.

[4] N. Marmiroli and E. Maestri, "Polymerase chain reaction (PCR),"

Food Toxicants Anal., vol. 5, no. 6, pp. 147-187, 2007.

[5] B. Haqi, and H. S. Setiawan, Aplikasi Absensi Dosen dengan Java dan Smartphone sebagai Barcode Reader. Elex Media Komputindo, 2019.

[6] W. Komputer, ShortCourse Series: Adobe Flash CS4. Penerbit Andi, 2012.

[7] D. Suprianto, "Membuat Aplikasi Desktop Menggunakan MySQL dan VB. Net," Jakarta: Mediakita, 2010.

[8] S. K. Rahayu, "Analisis budaya organisasi pada pengembangan sistem informasi di unikom," Maj. 
Ilm. UNIKOM, vol. 12, no. 2, 2014.

[9] E. Sutanta and K. Mustofa, "Kebutuhan Web Service Untuk Sinkronisasi Data Antar Sistem Informasi Dalam E-Gov Di Pemkab Bantul Yogyakarta," J. Teknol. Inf. Komun., vol. 1, no. 1, 2012.
[10] E. W. Fridayanthie and T. Mahdiati, "Rancang Bangun Sistem Informasi Permintaan Atk Berbasis Intranet (Studi Kasus: Kejaksaan Negeri Rangkasbitung)," J. Khatulistiwa Inform., vol. 4, no. 2, 2016. 